\title{
Забезпечення необхідної надійності функціонування каналів залізничного технологічного радіозв'язку
}

Проведено аналіз факторів, які впливають на забезпечення якісної та надійної роботи каналів рухомого радіозв'язку в умовах впливу інфраструктури залізниць. Визначені основні проблемні питання підвищення надійності функиіонування радіоканалів. Показано, щзо найбільш ефективними методами забезпечення необхідної надійності мереж технологічного радіозв'язку на залізничному транспорті є раціональне вирімення основних питань організації радіомереж, розрахунку каналів та удосконалення експлуатаційного контролю. Ці питання можуть вирішуватись на етапах проектування і впровадження без суттєвих додаткових витрат.

Ключові слова: залізничний технологічний радіозв'язок, надійність функціонування радіоканалів, модель забезпечення надійності, методи підвищення експлуатаційної надійності.

\begin{abstract}
Вступ
Радіозв'язок 3 рухомими об'єктами широко застосовується в усіх технологічних ланках роботи залізничного транспорту. Системи технологічного радіозв'язку безпосередньо використовуються для оперативного управління рухом поїздів і відносяться до категорії відповідальних систем [1].

Забезпечення необхідної надійності каналів рухомого радіозв'язку на залізницях, які працюють в складних умовах поширення радіохвиль, наявності глибоких інтерференційних флуктуацій напруженості поля, розосередженості об'єктів мережевої інфраструктури $є$ складною і актуальною задачею. Важливо підвищити надійність прогнозування енергетичних характеристик при розрахунках зон обслуговування в процесі проектування радіомереж. Обов'язковою умовою забезпечення безперебійної дії та високої якості каналів технологічного радіозв'язку $є$ ефективне технічне обслуговування в складних умовах експлуатації на рухомих об'єктах та впливу інфраструктури залізниць. Вирішення цих задач особливо важливо в умовах модернізації технологічного радіозв'язку, впровадження сучасних цифрових систем i освоєння нових діапазонів радіохвиль [2].
\end{abstract}

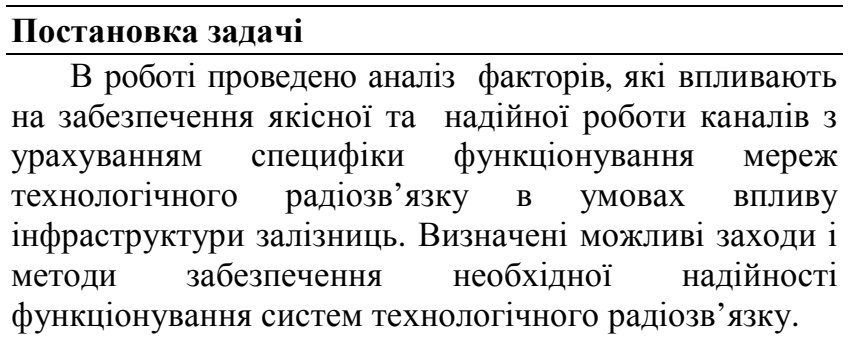

(C) А.О. Слізаренко, 2016

\section{Основні результати роботи}

В загальному випадку якість розглядають як сукупність властивостей, що обумовлюють здатність технічної системи задовольняти певні потреби у відповідності 3 іiї призначенням. Основні поняття, терміни та визначення встановлюються Міждержавним стандартом 3 управління якістю. Забезпечення надійності каналів рухомого радіозв'язку має суттєві відмінності від інших технічних систем.

Для характеристики мереж рухомого радіозв'язку використовують широко розгалужену багатокритеріальну систему показників якості [3]. Надійність - одна із основних характеристик якості технічних засобів. Кількісна характеристики експлуатаційної надійності оцінюється коефіцієнтом готовності $K_{\Gamma}$ і імовірністю безвідмовної роботи $P(\mathrm{t})$.

В каналах зв’ язку якісні показники можна умовно розділити на дві групи: зовнішні та внутрішні. Зовнішні параметри системи характеризують їі з точки зору користувача. При цьому зовнішні параметри залежать від сукупності внутрішніх, які визначають структуру системи [4].

До внутрішніх параметрів системи відносять: потужність передавача, чутливість приймальних пристроїв, характеристики антен, робочі частоти та ін. Внутрішні параметри визначають значення зовнішніх, які впливають на ефективність системи радіозв'язку.

Більшість параметрів передавачів і приймачів радіостанцій встановлюються державними стандартами.

Найважливішим зовнішнім параметром радіосистем є точність передачі інформації [4]. При передачі мовної інформації, яка ще домінує в мережах технологічного зв'язку, якість передачі визначається розбірливістю мови, гучністю, натуральністю, відсутністю завад. Показник розбірливості 
визначається шляхом проведення артикуляційних вимірювань за методикою, встановленою ГОСТ 16600-72. Електричні завади в каналі нормуються величиною псофометричної напруги.

В системах рухомого радіозв'язку на залізничному транспорті розширюється сфера передачі різної нетелефонної інформації. Вірність передачі дискретних сигналів є основною характеристикою, яка визначає міру відповідності прийнятого повідомлення переданому. Кількісною характеристикою вірності $€$ імовірність помилкового прийому символів [4]. За рекомендацією МСЕ імовірність помилки для передачі даних не повинна перевищувати $10^{-6}$ на символ (біт) кодової послідовності.

При аналізі надійності каналів радіозв'язку необхідно враховувати енергетичні характеристики радіоканалів та можливість втрати зв'язку внаслідок завмирання сигналів на трасах поширення радіохвиль. Задача забезпечення якості радіоканалів на етапі проектування радіомереж зводиться до визначення енергетичних характеристик каналів для розрахунку зон обслуговування i для вирішення проблем електромагнітної сумісності радіозасобів.

Аналіз умов забезпечення показників надійності радіоканалів необхідно розглядати на всіх етапах життєвого циклу радіозасобів:

- при розробці і виробництві радіостанцій;

- при проектуванні радіомереж та їх технічній експлуатації [5];

На рис. 1 показана модель каналу радіозв'язку 3 урахуванням основних чинників, які впливають на якість функціонування.

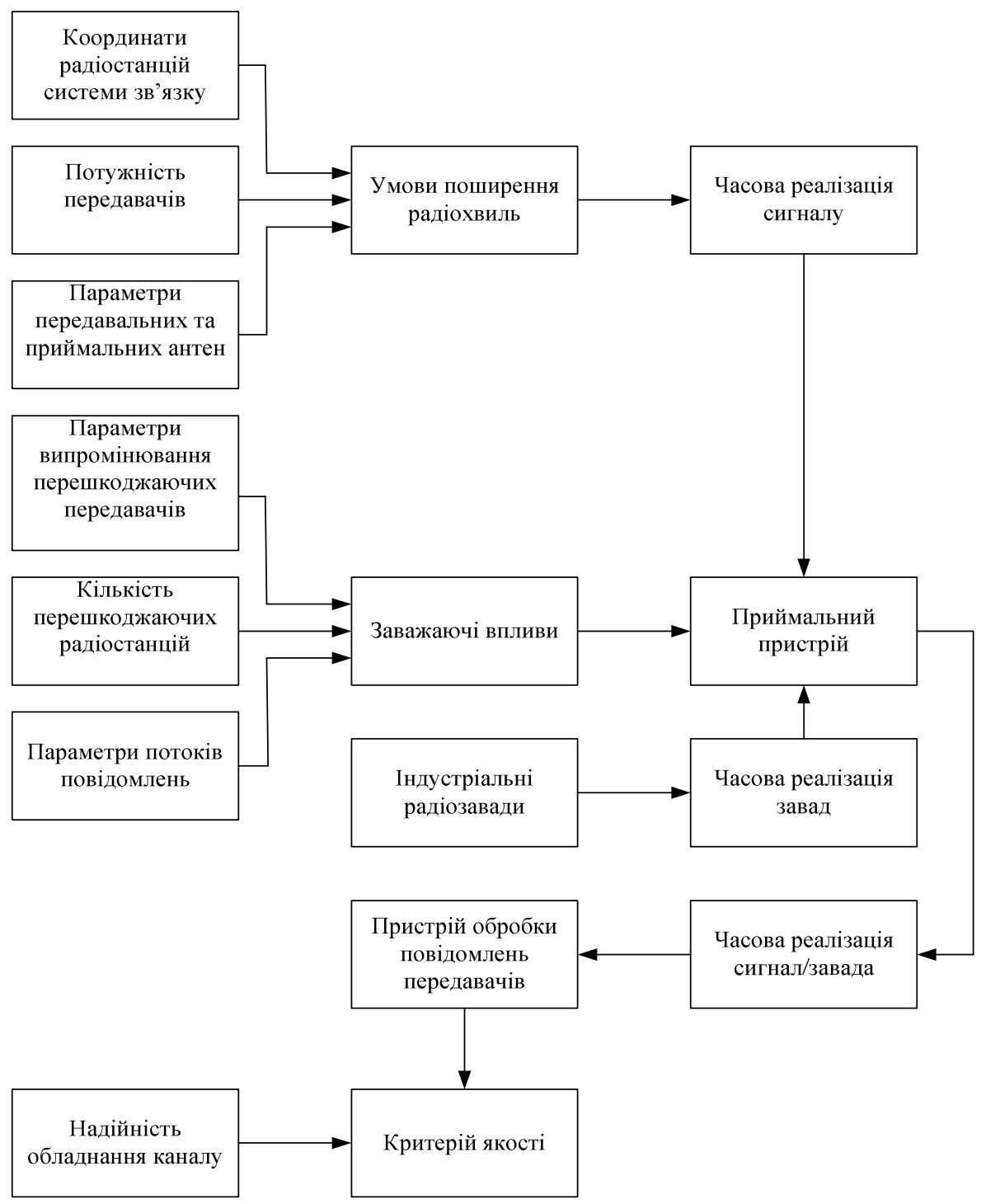

Рис. 1. Фактори впливу на якість функціонування радіоканалів 
Координати радіостанцій, потужності передавачів, параметри антен, що використовуються, визначають в конкретних умовах поширення радіохвиль часові реалізації корисного сигналу.

Індустріальні радіозавади в умовах електрифікованих залізниць впливають істотним чином на умови прийому радіосигналів. 3 метою зменшення рівнів радіозавад в використовуємих смугах радіочастот електрорухомий склад обладнують завадозахисними пристроями [1]. Виходячи 3 нормованих значень рівнів індустріальних радіозавад, на локомотивах та стаціонарних пунктах встановлюються мінімально допустимі рівні корисних сигналів, які необхідно забезпечити при проектуванні радіомереж, 3 метою забезпечення необхідної розбірливості мови або вірності прийому дискретних сигналів.

Передавачі заважаючих радіостанцій здійснюють вплив на прийом, утруднюючи забезпечення умов електромагнітної сумісності.

На виході приймального пристрою формується часова реалізація сигналу, що характеризується певним співвідношенням сигнал/завада, яке впливає на умови прийому одиночних елементів дискретного повідомлення. Застосування більш довершених методів кодування і обробки повідомлень дозволяє підвищити точність передачі даних i ефективність функціонування радіоканалу взагалі.

Особливу роль грає надійність обладнання радіоканалу, що безпосередньо впливає на якість його роботи. Будь-яка відмова радіозасобів виключає передачу повідомлень. У той же час навіть при ідеальній надійності обладнання радіоканалу невірний прийом повідомлення не виключається, наприклад, при погіршенні умов поширення радіохвиль.

На рис. 2 розглянуті основні методи підвищення якості функціонування радіоканалів в мережах рухомого зв'язку. Всі методи можна умовно розділити на три групи: експлуатаційно-технічні, підвищення завадостійкості прийому одиничних елементів сигналу і підвищення завадостійкості прийому повідомлення в цілому.

Поліпшення експлуатаційно-технічних характеристик радіоканалів передбачає підвищення надійності радіозасобів, раціональне проектування радіомереж, забезпечення електромагнітної сумісності і вдосконалення методів технічного обслуговування.

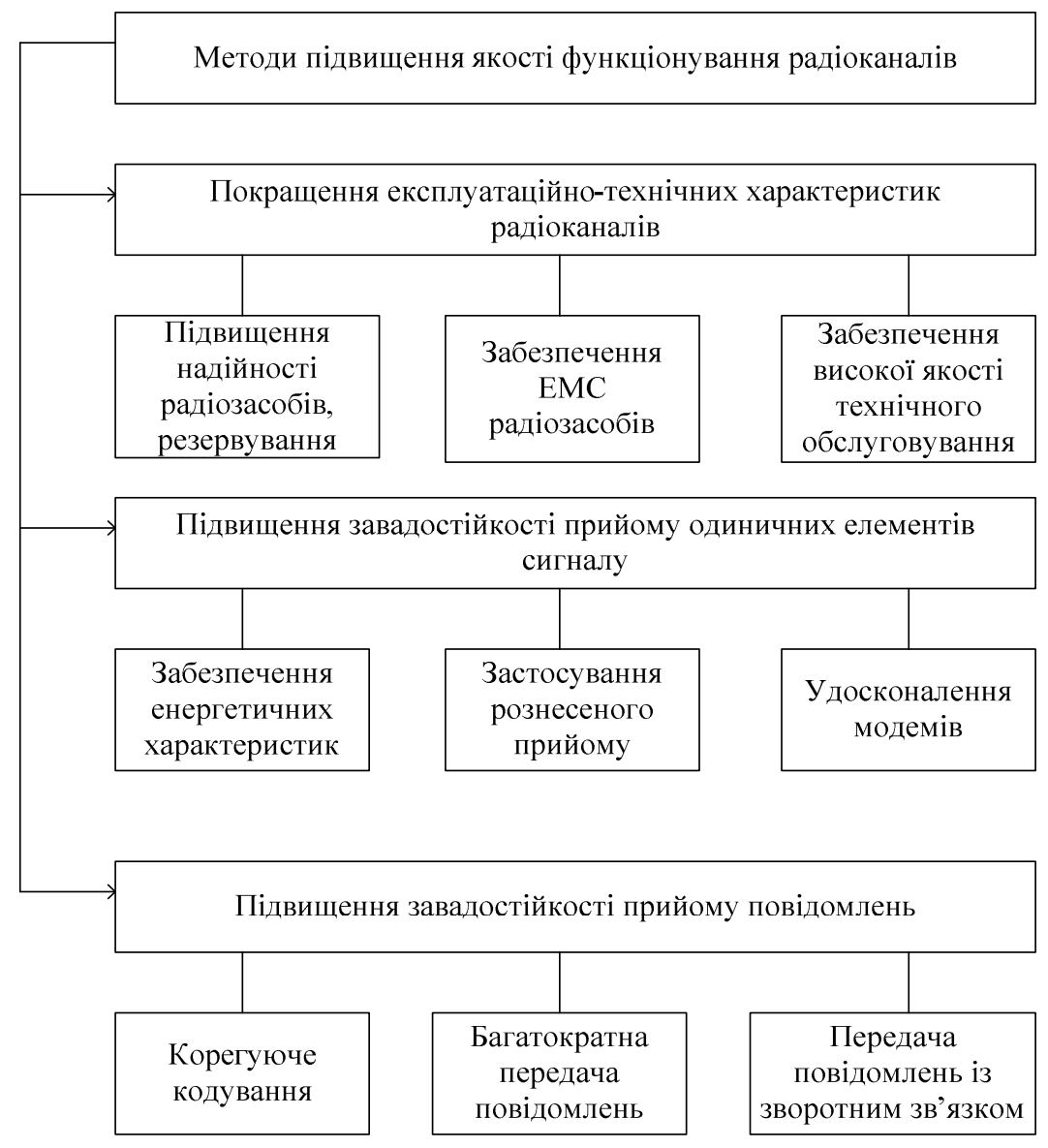

Рис. 2. Методи підвищення якості функціонування радіоканалів 
Забезпечення електромагнітної сумісності (ЕMC) радіозасобів вимагає аналізу електромагнітної обстановки, що реально складається на певний час. Рішення питань забезпечення ЕMC необхідно здійснювати на етапі проектування радіоканалів [4].

Умови надійного прийому одиночних елементів сигналу визначаються енергетичними характеристиками радіоканалів 3 метою створення на вході радіоприймального пристрою необхідного перевищення енергії радіосигналу над спектральною потужністю завад. Додаткові можливості можуть забезпечити відомі методи підвищення завадостійкості прийому повідомлень, що включають корегуюче кодування, багаторазову передачу повідомлень і передачу повідомлень із зворотнім зв'язком.

Можливості застосування кожного 3 перерахованих методів для підвищення вірності передачі в каналах рухомого радіозв'язку об'єктивно обмежені 3 техніко-економічних міркувань. Кращі результати досягаються за рахунок поєднання різних методів.

Створення загальної моделі радіотехнічних систем рухомого радіозв'язку, яка б враховувала всі фактори впливів, $\epsilon$ надзвичайно складною задачею, пї вирішення важке i неоднозначне. В таких умовах найбільш раціональним є створення моделей окремих ланок радіотехнічних систем і вирішення проблем забезпечення якості функціонування на рівні кожної із них.

Мережі рухомого радіозв'язку можна розглядати як складну систему, яка містить три різнорідні ланки. Перша ланка це технічні радіозасоби в широкому сенсі: передавальні і приймальні пристрої, засоби модуляції і завадостійкого кодування та ін. Забезпечення надійності в цьому сегменті є окремою проблемою, яка має вирішуватися на етапі розробки $\mathrm{i}$ виробництва радіозасобів.

Друга складова це середовище поширення радіосигналів та заходи пов'язані із забезпеченням необхідних енергетичних характеристик та стійкої роботи каналів в умовах глибоких просторових флуктуацій напруженості поля.

При розрахунку параметрів мереж радіозв'язку завжди вводиться поняття надійності зв'язку по полю $p$ - відсоток точок прийому, в яких просторово флуктуючий сигнал перевищує мінімально необхідний рівень прийому в межах відносно короткого відрізку шляху на максимально заданій відстані, відповідно до рекомендацій ITU-R з розрахунку дальності рухомого радіозв'язку [1]. При розрахунках зон обслуговування радіомереж на етапі проектування необхідно забезпечити певну імовірність перевищення мінімально-необхідного рівня корисних сигналів навіть в точках інтерференційних мінімумів напруженості поля.
Третю ланку складає система експлуатації та технічного обслуговування, яку розглядають як сукупність методів i алгоритмів технічного обслуговування, технічних засобів контролю i відповідного технічного персоналу, який здійснює організацію і підтримання засобів радіозв' язку в межах встановлених норм. Вдосконалення системи технічного обслуговування дозволяє своєчасно виявити відхилення характеристик апаратури на основі періодичного проведення вимірювань параметрів i функціонального контролю, а також скоротити час відновлення обладнання, що відмовило. Такі заходи $є$ важливим чинником забезпечення експлуатаційної надійності радіоканалів.

Виходячи із викладеного модель забезпечення надійності системи рухомого радіозв'язку можна представити у вигляді структурної схеми наведеної на рис. 3.

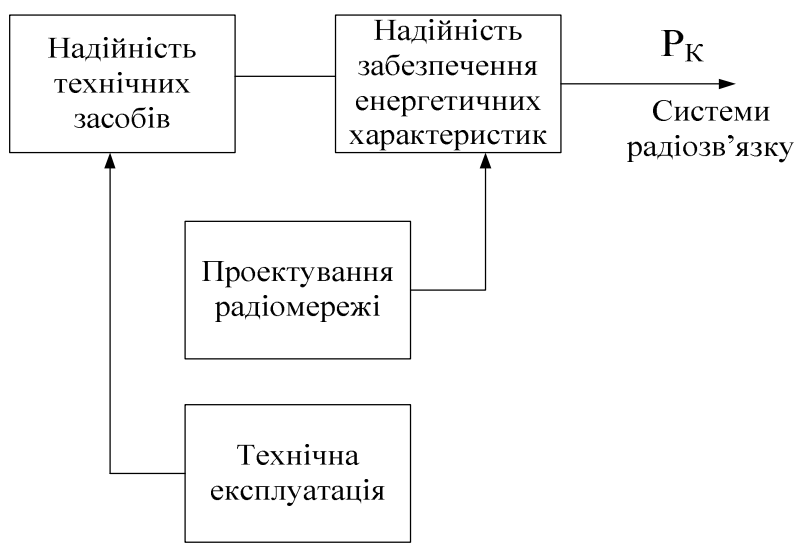

Рис. 3. Модель забезпечення надійності системи рухомого радіозв'язку

Імовірність безвідмовної роботи каналу радіозв'язку $P_{k}$, яка $\epsilon$ комплексним показником надійності, можна визначити як

$P_{\kappa}=1-\left(1-P_{m 3} \cdot P_{p c}\right)^{k}$,

де $P_{m 3}$ - імовірність безвідмовної роботи технічних засобів, при прийнятій системі технічної експлуатації, яка встановлюється за експлуатаційно - технічними характеристиками виробника;

$P_{p c}-$ вірогідність забезпечення необхідного рівня корисного сигналу для конкретних умов поширення радіохвиль при встановленій якості зв'язку, за умови виконання вимог ЕМС;

$k$ - кратність резервування використовуємих технічних засобів, яке застосовують при недостатній надійності одного радіоканалу. 
Впровадження сучасних технічних засобів, які мають високі власні показники безвідмовної роботи, забезпечує підвищення апаратної надійності технічних засобів. Удосконалення технічного обслуговування безумовно впливає на надійністні характеристики радіосистем, забезпечуючи підвищення показників безвідмовності технічних засобів. Але методи кількісної оцінки цього впливу ще не розроблені [5].

У високонадійних системах за необхідну імовірність безвідмовної роботи рекомендують приймати показник $P \geq 0,999$. В умовах рухомого залізничного технологічного радіозв'язку складно забезпечити імовірність безвідмовної роботи одного радіоканалу більше ніж 0,9-0,95 [1, 5].

Для підвищення надійності систем необхідно використовувати резервування обладнання в різних смугах частот, які виділені для технологічного радіозв'язку. Конкретні значення необхідної надійності визначаються в залежності від призначення каналів рухомого радіозв'язку [6].

Існуючі системи поїзного радіозв'язку організують в двох діапазонах радіохвиль: лінійні мережі в гектометровому - на єдиній для всіх залізниць частоті 2,13 МГц і зонні мережі в метровому - в смугах частот 160 МГц. Такий підхід забезпечує лише часткове резервування каналів тому, що системи мають різні функціональні можливості. Освоєння нових УКХ діапазонів радіохвиль дасть змогу забезпечення повноцінного функціонування дубльованих систем поїзного радіозв’ язку.

\begin{tabular}{l}
\hline Висновки \\
\hline Проведений аналіз показує, що найбільш \\
ефективними заходами забезпечення необхідної \\
надійності функціонування систем технологічного \\
радіозв'язку на залізничному транспорті є раціональне \\
розв'язання основних питань організації, проектування \\
i експлуатації радіоканалів на основі науково- \\
обгрунтованих методів. Важливо, що ці питання можна \\
вирішувати безпосередньо на етапі впровадження \\
більш сучасних технічних засобів радіозв'язку без \\
суттєвих додаткових економічних витрат. Вирішення \\
цих питань може скласти основні напрямки науково - \\
дослідних робіт з удосконалення і розвитку мереж \\
технологічного радіозв’язку на залізницях.
\end{tabular}

\section{Література}

1. Радиотехнические системы железнодорожного транспорта: учебник для вузов железнодорожного транспорта [Текст] / Ю.В. Ваванов, А.В. Елизаренко, А.А. Танцюра и др. М.: Транспорт, 1991. - 303 с.

2. Инфокоммуникации Российских железных дорог. Состояние и перспективы развития [Текст] / Под общ. ред. В.Н. Сазонова, Л.Е. Варакина, С.В. Липатова. - М.: МАС, 2006, - 192 с.
3. Радиотехнические системы передачи информации [Текст] / В.А. Борисов, В.В. Калмыков, Я.М. Ковальчук, Ю.Н. Себекин и др. Под ред. В.В. Калмыкова. - М.: Радио и связь, 1990. - 304 с.

4. Гуткин Л.С. Проектирование радиосистем и радиоустройств [Текст] / Л.С. Гуткин. - М.: Радио и связь, 1986. - 288 с.

5. Проектирование и техническая эксплуатация цифровых телекоммуникационных систем и сетей [Текст] / Е.Б. Алексеев, В.Н. Гордиенко, В.В. Крухмалев, А.Д. Моченов. - М.: Горячая линия - Телеком , 2008. - 392 с.

6. Роенков Д.Н. Методические указания по организации и рас чету сетей ПРС [Текст] /Д.Н. Роенков, Г.О. Коренной // «Автоматика, связь информатика» 2014 г. №6; С.18-20.

\section{Елизаренко А.А. Обеспечение необходимой надёжности функционирования каналов железнодорожной технологической радиосвязи.} Проведен анализ факторов, которые влияют на обеспечение качественной и надежной работы каналов подвижной радиосвязи в условиях воздействия инфраструктуры железных дорог. Определены основные проблемные вопросы повышения надежности радиоканалов. Показано, что наиболее эффективными методами повышения надежности сетей технологической радиосвязи на железнодорожном транспорте является рациональное решение основных вопросов организации радиосетей, расчета каналов и совершенствование эксплуатационного контроля. Эти вопросы могут решаться на этапах проектирования и внедрения без существенных дополнительных затрат.

Ключевые слова: железнодорожная технологическая связь, надежность функционирования радиоканалов, модель обеспечения надежности, методы повышения эксплуатационной надежности.

Yelizarenko A.O. Ensuring the required reliability of railway technological radio communication channel. The analysis of factors affecting the provision of quality and reliable performance of mobile radio communication channels under the impact of the railway infrastructure has been conducted. Key issues concerning the improvement of the reliability of radio channels have been identified.

The model ensuring the reliability of mobile radio systems can be considered consisting of three links. The first link is a technical radio equipment in the broad sense, the transmitting and receiving devices, the modulation and error-correcting coding, etc. Ensuring reliability in this segment is a separate issue that should be resolved at the stage of development and production of radio equipment. The second component is the environment of radio 
propagation and activities associated with providing the necessary energy characteristics and stable operation of channels in deep spatial fluctuations of the field strength. The third link is the system operation and maintenance, considered as a set of methods and algorithms for maintenance of engineering control and appropriate technical staff, which carries out the organization and maintenance of radio communications within the established norms.

It is shown that the most effective methods of improving the reliability of networks of technological radio communication on railway transport is the rational solution of the major issues of the organization of radio network, calculating channels, and improving operational control. These issues can be solved during design and implementation stages without significant additional costs. Key words: railway technological radio communication, reliability of radio channel operation, model reliability, methods to improve operational reliability.

Рецензент д.т.н., професор Бойнік А.Б. (УкрдУзТ)

Поступила 09.02.2016 p.

Yelizarenko A.O., Candidate of Engineering Science, Ukrainian State University of Railway Transport, Kharkiv, Ukraine.

Слізаренко А.О., к.т.н., стариий викладач кафедри транспортного зв'язку, Украӥнський держсавний університет залізничного транспорту, Харків, Украӥна. 